\title{
PEMILIHAN BEBERAPA CAMPURAN LAPIS TIPIS ASPAL PANAS UNTUK APLIKASI DI LAPANGAN.
}

\author{
Dicky Faisal $^{1)}$, Ary Setyawan ${ }^{2)}$, Agus Sumarsono ${ }^{3)}$ \\ ${ }^{1)}$ Mahasiswa Program S1 Teknik Sipil, Universitas Sebelas Maret \\ 2) 3) Pengajar Program Studi Teknik Sipil , Universitas Sebelas Maret \\ Jalan Ir Sutami 36A, Surakarta 57126 E-mail : dickyfaisal94@yahoo.com
}

\begin{abstract}
In the Thin Surfacing Hot Mix Asphalt research that has been done using different blends on research. Blends who compare are Thin Surfacing Hot Mix Asphalt with Crumb Rubbrer, Retona Blend E55, Starbit E-55, Ethylene Vinyl Acetate and asphalt pen 60/70. Every blends had different characteristic based on type of blends. Then the question, which is the best type of blend for free trail scale? The purpose of this research is to compare the result of research Thin Surfacing Hot Mix Asphalt that has been done to selection which is the best then use for free trial scale and determine number of compaction for optimum volumetric for free scale trial.

The method used in this research is comparison and experimental. Experimental conduct in Highway Laboratory Sebelas Maret University Surakarta and in Madegondo village, Grogol subdistrict, Sukoharjo district. The dimension of free trial scale sample is $1 \mathrm{~m} \times 3 \mathrm{~m}$ with $3 \mathrm{~cm}$ dense. The various compaction are 10, 15 and 20 compaction.

The result from analysis comparison blend is Starbit e-55 blend has best stability and use for free trial scale. Then for more number of compaction show better volumetric value but have asymptotic value.
\end{abstract}

\section{(Key Words : Thin Surfacing, Marshall,Volumetric)}

Dalam penelitian-penelitian Thin Surfacing Hot Mix Asphalt yang telah diakukan sebelumnya telah digunakan beberapa campuran. Campuran yang dibandingkan adalah Thin Surfacing Hot Mix Asphalt dengan campuran Crumb Rubbrer, Retona Blend E55, Starbit E-55, Etbylene Vinyl Acetate dan Aspal pen 60/70. Setiap campuran memiliki karakterisitik yang berbeda satu sama lain tergantung campuran yang digunakan. Kemudian muncul pertanyaan jenis campuran manakah yang terbaik dari sisi nilai Marshall Quotient untuk diaplikasikan di lapangan? Tujuan penelitian ini adalah membandingkan hasil penelitian Thin Surfacing Hot Mix Asphalt yang terdahulu untuk diseleksi mana yang terbaik yang kemudian akan di aplikasikan di lapangan dan menentukan jumlah gilasan optimum untuk menentukan nilai volumetrik optimum yang kemudian akan diaplikasikan di lapangan.

Metode yang digunakan dalam penelitian ini adalah metode Perbandingan dan Eksperimental. Eksperimental dilaksanakan di Laboratorium Jalan Raya Universitas Sebelas Maret Surakarta dan di desa Madegondo, kecamatan Grogol, kabupaten Sukoharjo. Adapun benda uji yang dibuat di lapangan adalah berukuran $1 \mathrm{~m}$ x $3 \mathrm{~m}$ dengan tebal sekitar $3 \mathrm{~cm}$. Variasi gilasan yang dilakukan adalah sebesar 10, gilasan, 15 gilasan dan 20 gilasan.

Hasil dari analisis perbandingan campuran menunjukkan campuran Starbit e-55 mempunyai nilai stabilitas terbaik dan digunakan untuk aplikasi di lapangan. Sedangkan dengan jumlah gilasan yang diperbanyak menghasilkan nilai volumetric yang semakin baik namun memiliki nilai yang asimptotik.

(Kata kunci : Thin Surfacing, Marshall, Volumetric)

\section{PENDAHULUAN}

Penerapan Thin Surfacing Hot Mix Asphalt merupakan salah satu teknologi yang berwawasan lingkungan (Greenroad) dan jalan berkeselamatan (Safety Road) yang sedang dikembangkan 
sebagai usaha preventif dan resurfacing untuk perkerasan jalan. Thin Surfacing Hot Mix Asphalt memiliki ketebalan antara 25-40 $\mathrm{mm}$.

Untuk meningkatkan kekuatan pada perkerasan Thin Surfacing yang mempunyai ketebalan yang relatif tipis banyak dilakukan penambahan bahan tertentu pada campuran. Bahan tambah yang digunakan diantaranya adalah Crumb Rubber, Ethylene Vinyl Acetate, Retona Blend 55, Starbit E-55 dan lain-lain. Pada setiap campuran menghasilkan nilai marshall quoient yang berbeda-beda, nilai marshaal quotient ini yang dijadikan dasar pemilihan campuran untuk digunakan pada aplikasi di lapangan

Dari penambahan bahan tambah pada campuran dihasilkan peningkatan yang signifikan dari pada tanpa bahan tambah. Dengan penambahan bahan tambah tersebut karakteristik campuran pun bertambah antara lain ditinjau dari segi stabilitas, flow, densitas dan porositas. Maka dari itu dalam penelitian ini membandingkan pemakaian bahan tambah pada campuran Thin Surfacing untuk akhirnya dapat diaplikasikan di lapangan.

\section{LANDASAN TEORI}

Thin Surface for Treatment didefinisikan sebagai perawatan lapis tipis menggunakan sistem hotmix sebagaimana didefinisikan dalam spesifikasi standar atau ketentuan khusus dari California Department of Transportation.Tujuan dari perbaikan lapis tipis ini adalah sebagai lapisan non-struktural yang diterapkan untuk pemeliharaan lapis permukaan perkerasan, baik korektif atau preventif. Secara umum, perawatan lapis tipis mempunyai ketebalan kurang dari $1 \frac{1}{2}$ inci $(37,5 \mathrm{~mm})$. (Caltrans, 2007).

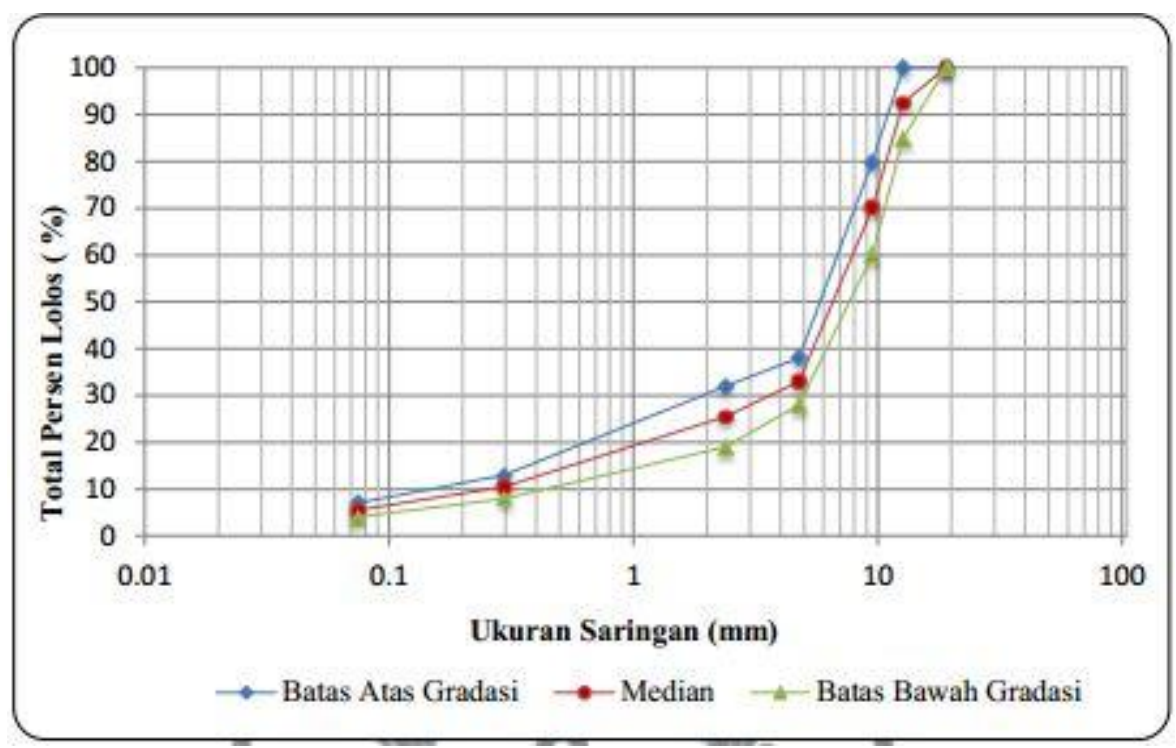

Gambar 1 Gradasi Agregat Thin Surfacing HMA NAPA, North Carolina

Spesifikasi campuran Thin Surfacing Hot Mix Asphalt mengacu pada National Asphalt Pavement Association (NAPA). Gradasi yang digunakan pada campuran ini adalah gradasi envelop yang merupakan standar dari North Carolina. Maksimum ukuran agregat penyusun Thin Surfacing Hot Mix Asphalt ini adalah 12,5 mm atau tertahan oleh saringan nomor 1/2.

\section{TAHAPAN PENELITIAN}

Peneiliti membandingkan 5 campuran Thin Surfacing Hot Mix Asphalt yang telah dilakukan oleh peneliti sebelumnya. Mempersiapkan alat dan bahansebelum memulai penelitian. Melakukan uji bahan untuk mengetahui kelayakan untuk sampel thin surfacing. Membuat sampel di lab untuk mencari kadar aspal optimum, serta melakukan uji Marshall dan volumetric. 
Menghampar aspal dilapangan dengan variasi jumlah gilasan untuk melakukan uji skid resistance dan kemudian dilakukan coring untuk mengambil sampel untuk uji volumetric. Melakukan analisis data untuk mendapat kesimpulan hubungan antar variable yang diteliti saat penelitian.Melakukan pengambilan kesimpulan dari analisis data yang berhubungan dengan tujuan dari penelitian. Berikut diagram alir yang dilaksanankan pada penelitian:

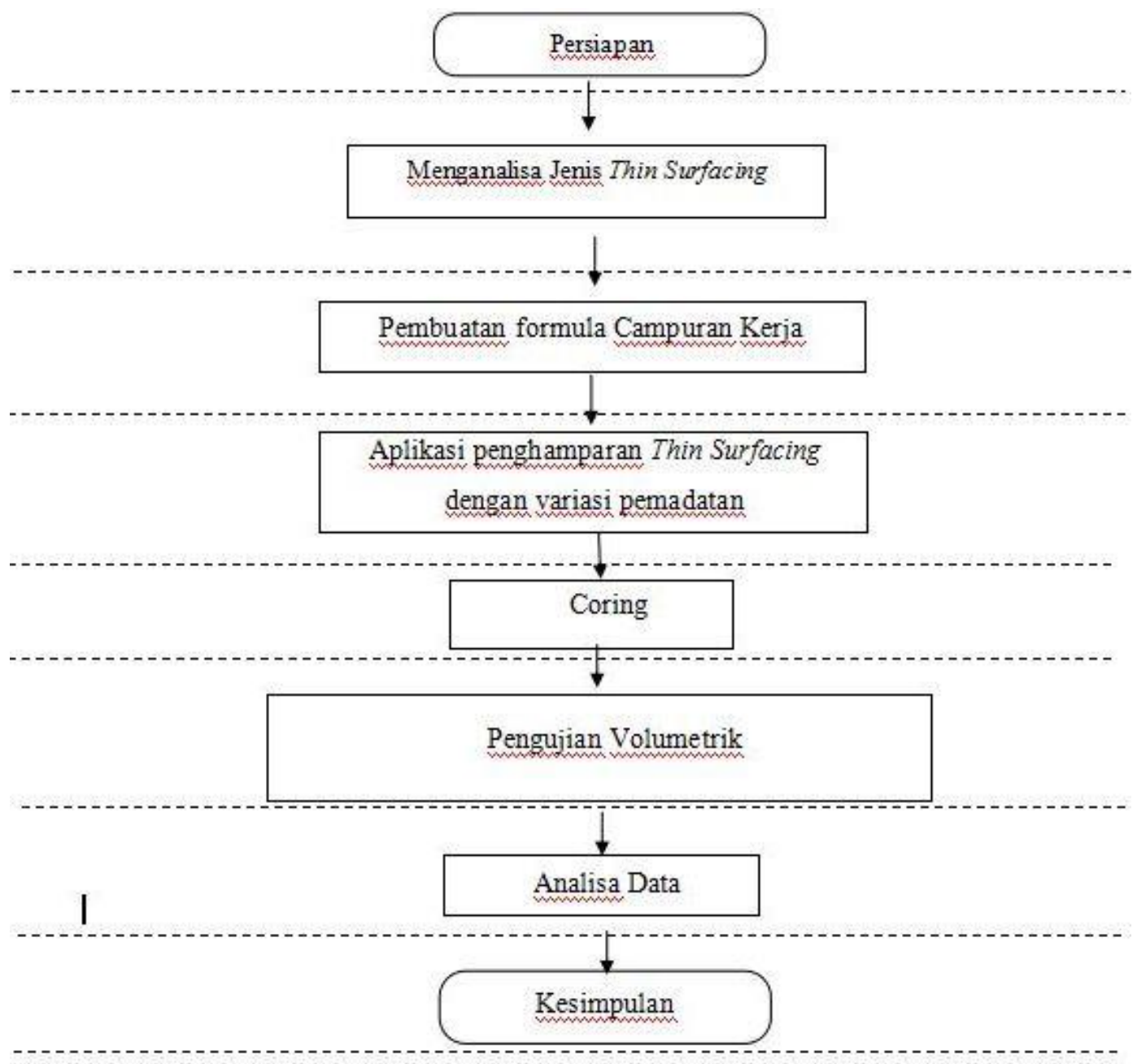

Gambar 2 Diagram alir penelitian

Dari digram alir diatas dapat diimpulkan inti dari pebelitian ini adalah membandingkan hasil penelitian campuran Thin Surfacing Hot Mix Asphalt yang telah dilakukan oleh penelitian sebelumnya kemudian yang terbaik diaplikasikan di lapangan.

\section{HASIL DAB PEMBAHASAN}

Berikut hasil penelitian campuran Thin Surfacing Hot Mix Asphalt yang telah dilakukan oleh peneliti sebelumnya: 
Tabel 1 Karakteristik beberapa campuran Thin Surfacing Hot Mix Asphalt

\begin{tabular}{llllll}
\hline Karakteristik & $\begin{array}{l}\text { Retona } \\
\text { Blend 55 }\end{array}$ & $\begin{array}{l}\text { Starbit E- } \\
\mathbf{5 5}\end{array}$ & EVA & $\begin{array}{l}\text { PEN } \\
\mathbf{6 0 / 7 0}\end{array}$ & $\begin{array}{l}\text { Crumb } \\
\text { Rubber }\end{array}$ \\
\hline $\begin{array}{l}\text { Kadar Aspal } \\
\text { Optimum (\%) }\end{array}$ & 5,87 & 5,53 & 5,8 & 5,84 & 4,49 \\
\hline Stabilitas (kg) & 525,61 & $1.024,60$ & 930 & 782,18 & 730,09 \\
\hline $\begin{array}{l}\text { Marshall Quotient } \\
\text { (kg/mm) }\end{array}$ & 251,25 & 466,09 & 310 & 353,26 & 358.64 \\
\hline Flow $(\mathrm{mm})$ & 2,12 & 2,21 & 2,9 & 2,21 & 1,86 \\
\hline Density $(\mathrm{gr} / \mathrm{cc})$ & 2,06 & 2,17 & 2,05 & 2,24 & 2,11 \\
\hline Void in $m \times(\%)$ & 18,44 & 8,03 & 4,5 & 4,97 & 7,87 \\
\hline
\end{tabular}

Pada Tabel 1 menunjukkan data campuran Thin Surfacing Hot Mix Asphalt dengan aspal Starbit E-55 memiliki nilai Marshall Quotient paling tinggi yaitu 466,09 $\mathrm{kg} / \mathrm{mm}$, sehingga pada penelitian ini digunakan Thin Surfacing Hot Mix Asphalt dengan aspal Starbit E-55 untuk di aplikasikan di lapangan.

Bahan yang digunakan penelitian ini adalah agregat, aspal polimer starbit E-55.Pemeriksaan dilakukan di Laboratorium Jalan Raya Fakultas Teknik Universitas Sebelas Maret Surakarta.

Tabel 2. Hasil Pemeriksaan Gradasi agregat

\begin{tabular}{cccccc}
\hline & ukuran 1" & \multicolumn{2}{c}{ ukuran 1/2" } & \multicolumn{2}{c}{ ukuran abu batu } \\
\hline $\begin{array}{c}\text { No } \\
\text { Saringan }\end{array}$ & $\begin{array}{c}\text { Komulatif } \\
\text { Lolos }(\%)\end{array}$ & $\begin{array}{c}\text { No } \\
\text { Saringan }\end{array}$ & $\begin{array}{c}\text { Komulatif } \\
\text { Lolos }(\%)\end{array}$ & $\begin{array}{c}\text { No } \\
\text { Saringan }\end{array}$ & $\begin{array}{c}\text { Komulatif } \\
\text { Lolos }(\%)\end{array}$ \\
\hline $3 / 4^{\prime \prime}$ & 100 & $3 / 4^{\prime \prime}$ & 100 & $3 / 4^{\prime \prime}$ & 100 \\
\hline $1 / 2^{\prime \prime}$ & 72.69 & $1 / 2^{\prime \prime}$ & 99.22 & $1 / 2^{\prime \prime}$ & 100 \\
\hline $3 / 8^{\prime \prime}$ & 22.6 & $3 / 8^{\prime \prime}$ & 93.22 & $3 / 8^{\prime \prime}$ & 100 \\
\hline 4 & 1.61 & 4 & 37.37 & 4 & 97.3 \\
\hline 8 & 1.49 & 8 & 5.49 & 8 & 90.53 \\
\hline 50 & 1.37 & 50 & 1.92 & 50 & 37.67 \\
\hline 200 & 0.6 & 200 & 0.52 & 200 & 13.06 \\
\hline PAN & 0 & PAN & 0 & PAN & 0 \\
\hline
\end{tabular}

Ketiga agregat pada tabel 2 menunjukkan kemudian dicampur agar sesuaidengan spesifikasi. Pencampuran ketiga agregat diatas menggunakan metode grafis sehingga menghasilkan perbandingan berikut:

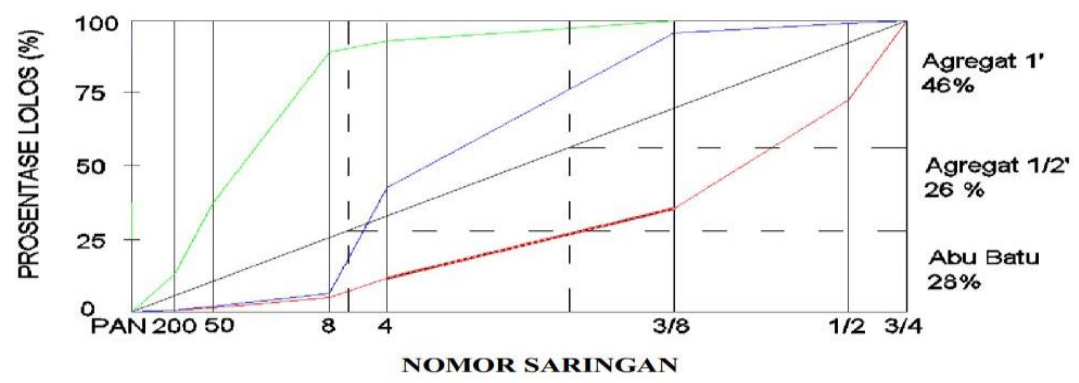

Gambar 3 Pencampuran Agregat 
Dari gambar diatas diambil perbandingan campuran agregat 1' $46 \%$, agregat $1 / 2$ ' $26 \%$ dan abu batu $28 \%$.

Tabel 3. Hasil pencampuran agregat

\begin{tabular}{|c|c|c|c|c|c|c|c|c|}
\hline \multirow[b]{2}{*}{$\begin{array}{l}\text { No } \\
\text { Saringan }\end{array}$} & \multicolumn{3}{|c|}{ Komulatif Lolos (\%) } & \multirow{2}{*}{$\begin{array}{l}\text { Agregat } \\
\text { '1 x } \\
46 \%\end{array}$} & \multirow{2}{*}{$\begin{array}{l}\text { Agregat } \\
1 / 2^{\prime} \times \\
26 \%\end{array}$} & \multirow{2}{*}{$\begin{array}{l}\text { Abu } \\
\text { Batu } \\
\text { x } 28 \%\end{array}$} & \multirow{2}{*}{$\begin{array}{l}\text { Gradasi } \\
\text { Agregat } \\
\text { Gabungan }\end{array}$} & \multirow[b]{2}{*}{ Spesifikasi } \\
\hline & $\begin{array}{l}\text { Agregat } \\
1,\end{array}$ & $\begin{array}{l}\text { Agregat } \\
1 / 2\end{array}$ & $\begin{array}{l}\text { Abu } \\
\text { Batu }\end{array}$ & & & & & \\
\hline $3 / 4 "$ & 100 & 100 & 100 & 46 & 26 & 28 & 100 & 100 \\
\hline $1 / 2 "$ & 72.69 & 99.22 & 100 & 33.44 & 25.8 & 28 & 87.23 & $85-100$ \\
\hline $3 / 8 ”$ & 22.6 & 93.22 & 100 & 10.4 & 24.24 & 28 & 62.63 & $60-80$ \\
\hline \#4 & 1.61 & 37.37 & 97.3 & 0.74 & 9.72 & 27.24 & 37.7 & $28-38$ \\
\hline$\# 8$ & 1.49 & 5.49 & 90.53 & 0.69 & 1.43 & 25.35 & 27.46 & $19-32$ \\
\hline$\# 50$ & 1.37 & 1.92 & 37.67 & 0.63 & 0.5 & 10.55 & 11.68 & $8-13$ \\
\hline \#200 & 0.6 & 0.52 & 13.06 & 0.28 & 0.14 & 3.66 & 4.07 & $4-7$ \\
\hline PAN & 0 & 0 & 0 & 0 & 0 & 0 & 0 & 0 \\
\hline
\end{tabular}

Pada tabel 3 menunjukkan pencampuran agregat yang didapat dari metode grafis sebelumnya menghasilkan campuran yang memenuhi spesifikasi Thin Surfacing Hot Mix Asphalt yang mengacu dari National Asphalt Pavement Association (NAPA)

\section{Penentuan Kadar Aspal Optimum}

Penentuan kadar aspal optimum dilakukan dengan pengujian Marshall. Dalam pengujian Marshall dilakukan variasi kadar aspal yaitu 4,5 \%, 5\%, 5,5\%, 6\%, dan 6,5\%.

Tabel 4. Data Berat Sampel

\begin{tabular}{|c|c|c|c|c|c|c|c|c|}
\hline \multirow{2}{*}{$\begin{array}{c}\text { Kode } \\
\text { sampel }\end{array}$} & \multirow{2}{*}{$\begin{array}{c}\% \text { Kadar } \\
\text { aspal }\end{array}$} & \multicolumn{2}{|c|}{ Berat di udara (gr) } & \multirow{2}{*}{$\begin{array}{l}\text { Berat di air } \\
\text { (gr) }\end{array}$} & \multicolumn{4}{|c|}{ Tebal benda uji (mm) } \\
\hline & & Kering & SSD & & 1 & 2 & 3 & 4 \\
\hline $4.5 \mathrm{a}$ & 4.5 & 471.2 & 482.4 & 270.7 & 26.4 & 26.5 & 26.5 & 26.5 \\
\hline $4.5 \mathrm{~b}$ & 4.5 & 469.9 & 481.8 & 268.4 & 27.3 & 27.2 & 27.1 & 27.3 \\
\hline $4.5 c$ & 4.5 & 473.9 & 486.2 & 272.8 & 26.5 & 26.4 & 26.5 & 26.4 \\
\hline $5 \mathrm{a}$ & 5 & 473.2 & 484.7 & 272.5 & 27.1 & 27.1 & 27.2 & 27.3 \\
\hline $5 b$ & 5 & 474.8 & 485.9 & 273.3 & 26.5 & 26.5 & 26.4 & 26.5 \\
\hline $5 c$ & 5 & 478.1 & 494.1 & 277.3 & 26.8 & 26.7 & 26.7 & 26.8 \\
\hline $5.5 a$ & 5.5 & 475.8 & 487.2 & 274.8 & 26.3 & 26.4 & 26.3 & 26.3 \\
\hline $5.5 \mathrm{~b}$ & 5.5 & 478.1 & 490.1 & 275.9 & 26.2 & 26.1 & 26.1 & 26 \\
\hline $5.5 c$ & 5.5 & 481.1 & 489.9 & 273.7 & 26.9 & 27 & 26.9 & 27.1 \\
\hline $6 a$ & 6 & 478.6 & 492.7 & 279.3 & 27 & 27.1 & 27 & 26.9 \\
\hline $6 \mathrm{~b}$ & 6 & 483.6 & 496.1 & 280.4 & 27.7 & 27.6 & 27.6 & 27.7 \\
\hline $6 c$ & 6 & 483.2 & 493.6 & 277.8 & 27.2 & 27.2 & 27.3 & 27.2 \\
\hline $6.5 \mathrm{a}$ & 6.5 & 488.7 & 499.3 & 283.7 & 26.9 & 26.8 & 26.8 & 26.8 \\
\hline $6.5 \mathrm{~b}$ & 6.5 & 484 & 497.2 & 281.6 & 27.4 & 27.3 & 27.3 & 27.4 \\
\hline $6.5 \mathrm{c}$ & 6.5 & 480.1 & 488.9 & 273.1 & 26.2 & 26.2 & 26.2 & 26.3 \\
\hline
\end{tabular}


Pada Tabel 4 menunjukkan data berat masing-masing benda uji diatas kemudian diolah untuk mencari nilai volumetrik campuran yaitu nilai densitas, nilai void in mix dan nilai specific gravity mix.

Tabel 5. Hasil Uji Volumetrik sampel lab

\begin{tabular}{|c|c|c|c|}
\hline kode sampel & $\begin{array}{c}\text { Density } \\
\left(\mathrm{gr} / \mathrm{cm}^{3}\right)\end{array}$ & $\begin{array}{l}\text { spesific gravity } \\
\text { mix }\left(\mathrm{gr} / \mathrm{cm}^{3}\right)\end{array}$ & $\begin{array}{c}\text { Void In Mix } \\
(\%)\end{array}$ \\
\hline $4.5 \mathrm{a}$ & 2.226 & \multirow{3}{*}{2.395} & 7.06 \\
\hline $4.5 \mathrm{~b}$ & 2.202 & & 8.06 \\
\hline $4.5 c$ & 2.221 & & 7.28 \\
\hline rata - rata & 2.216 & rata - rata & 7.47 \\
\hline $5 a$ & 2.230 & \multirow{3}{*}{2.379} & 6.27 \\
\hline $5 b$ & 2.233 & & 6.13 \\
\hline $5 c$ & 2.205 & & 7.31 \\
\hline rata - rata & 2.223 & rata - rata & 6.57 \\
\hline $5.5 \mathrm{a}$ & 2.240 & \multirow{3}{*}{2.363} & 5.22 \\
\hline $5.5 \mathrm{~b}$ & 2.232 & & 5.56 \\
\hline $5.5 \mathrm{c}$ & 2.225 & & 5.85 \\
\hline rata - rata & 2.232 & rata - rata & 5.54 \\
\hline $6 a$ & 2.243 & \multirow{3}{*}{2.347} & 4.48 \\
\hline $6 \mathrm{~b}$ & 2.242 & & 4.51 \\
\hline $6 \mathrm{c}$ & 2.239 & & 4.64 \\
\hline rata - rata & 2.241 & rata - rata & 4.54 \\
\hline $6.5 \mathrm{a}$ & 2.267 & \multirow{3}{*}{2.333} & 2.83 \\
\hline $6.5 \mathrm{~b}$ & 2.245 & & 3.77 \\
\hline $6.5 c$ & 2.225 & & 4.63 \\
\hline rata - rata & 2.246 & rata - rata & 3.74 \\
\hline
\end{tabular}

Pada Tabel 5 menunjukkan nilai volumetrik yang paling baik seiring dengan naiknya kadar aspal campuran Thin Surfacing Hot Mix Asphalt.

Tabel 6. Hasil Pengujian Marshall sampel di lab.

\begin{tabular}{|c|c|c|c|c|c|c|c|}
\hline \multirow{2}{*}{$\begin{array}{c}\text { No. } \\
\text { sampel }\end{array}$} & \multirow[b]{2}{*}{$\%$ aspal } & \multicolumn{4}{|c|}{ Stabilitas } & \multirow[b]{2}{*}{ flow } & \multirow{2}{*}{$\begin{array}{l}\text { Marshall } \\
\text { Quotient }\end{array}$} \\
\hline & & dial & kalibrasi & $\begin{array}{c}\text { koreksi } \\
\text { tebal }\end{array}$ & koreksi & & \\
\hline & $\%$ & $\mathrm{~kg}$ & $\mathrm{~kg}$ & & $\mathrm{~kg}$ & $\mathrm{~mm}$ & $\mathrm{~kg} / \mathrm{mm}$ \\
\hline $1 \mathrm{a}$ & 4.5 & 14 & 307.563 & 5.10 & 1568.573 & 2.80 & 560.205 \\
\hline B & 4.5 & 13 & 285.595 & 4.90 & 1399.413 & 2.90 & 482.556 \\
\hline $\mathrm{C}$ & 4.5 & 16 & 351.501 & 5.10 & 1792.655 & 2.65 & 676.474 \\
\hline \multicolumn{5}{|c|}{ Rata - rata } & 1586.880 & 2.78 & 573.078 \\
\hline $2 \mathrm{a}$ & 5 & 16 & 351.501 & 4.90 & 1722.355 & 2.60 & 662.444 \\
\hline $\mathrm{B}$ & 5 & 15 & 329.532 & 5.10 & 1680.614 & 2.30 & 730.702 \\
\hline $\mathrm{C}$ & 5 & 15 & 329.532 & 5.07 & 1670.728 & 2.70 & 618.788 \\
\hline \multicolumn{5}{|c|}{ Rata - rata } & 1691.232 & 2.53 & 670.645 \\
\hline
\end{tabular}




\begin{tabular}{|c|c|c|c|c|c|c|c|}
\hline $3 \mathrm{a}$ & 5.5 & 16 & 351.501 & 5.12 & 1799.685 & 2.10 & 856.993 \\
\hline B & 5.5 & 18 & 395.439 & 5.17 & 2044.417 & 2.40 & 851.841 \\
\hline C & 5.5 & 15 & 329.532 & 5.04 & 1660.842 & 2.65 & 626.733 \\
\hline \multicolumn{5}{|c|}{ Rata - rata } & 1834.981 & 2.38 & 778.522 \\
\hline B & 6 & 12 & 263.626 & 5.04 & 1328.674 & 2.60 & 511.028 \\
\hline $\mathrm{D}$ & 6 & 14 & 307.563 & 4.60 & 1414.791 & 2.10 & 673.710 \\
\hline $\mathrm{E}$ & 6 & 13 & 285.595 & 4.90 & 1399.413 & 2.40 & 583.089 \\
\hline \multicolumn{5}{|c|}{ Rata - rata } & 1380.959 & 2.37 & 589.276 \\
\hline $5 \mathrm{a}$ & 6.5 & 9 & 197.719 & 5.080 & 1004.414 & 2.80 & 358.719 \\
\hline $\mathrm{B}$ & 6.5 & 11 & 241.657 & 4.870 & 1176.869 & 2.60 & 452.642 \\
\hline $\mathrm{C}$ & 6.5 & 10 & 219.688 & 5.140 & 1129.197 & 2.50 & 451.679 \\
\hline \multicolumn{5}{|c|}{ Rata - rata } & 1103.493 & 2.63 & 421.013 \\
\hline
\end{tabular}

Dengan metode regresi dari data niali rata-rata marshall quotient didapat kadar aspal optimum sebesar $5.3 \%$

Dari nilai densitas rata-rata campuran dapat diketahui kebutuhan material untuk pembuatan benda uji yang berukuran $1 \mathrm{~m} \times 3 \mathrm{~m} \times 3 \mathrm{~cm}$. Berikut kebutuhan tiap material :
1. Aspal
$=201 \mathrm{~kg} \times 5,3 \%$
$=10,653 \mathrm{~kg}$
2. Agregat ukuran 1'
$=(201 \mathrm{~kg}-10,653) \times 46 \%$
$=87,56 \mathrm{~kg}$
3. Agregat ukuran 1/2'
$=(201 \mathrm{~kg}-10,653) \times 26 \%$
$=49,49 \mathrm{~kg}$
4. Abu batu
$=(201 \mathrm{~kg}-10,653) \times 28 \%$
$=52,30 \mathrm{~kg}$

\section{Hasil Uji Volumetrik Sampel Hasil Coring}

Pengambilan sampel di lapangan menggunakan coredrill untuk dilakukan beberapa pengujian yakni uji volumetric. Pertama dilakukan uji volumetrik setelah proses core selesai dilakukan. Dari uji volumetrik ini didapat nilai densitas dan porositas

Tabel 7. Data berat sampel hasil coring

\begin{tabular}{|c|c|c|c|c|c|c|c|c|}
\hline \multirow{2}{*}{$\begin{array}{c}\text { Kode } \\
\text { sampel }\end{array}$} & \multirow{2}{*}{$\begin{array}{c}\% \\
\text { Kadar } \\
\text { aspal }\end{array}$} & \multicolumn{2}{|c|}{ Berat di udara $(g r)$} & \multirow{2}{*}{$\begin{array}{l}\text { Berat di } \\
\text { air }(g r)\end{array}$} & \multicolumn{4}{|c|}{ Tebal benda uji (mm) } \\
\hline & & Kering & SSD & & 1 & 2 & 3 & 4 \\
\hline $10 \mathrm{a}$ & 5.3 & 543.9 & 546.6 & 296.2 & 33.35 & 31.3 & 33.3 & 31.85 \\
\hline $10 \mathrm{~b}$ & 5.3 & 707.1 & 710.2 & 377.8 & 42.2 & 40.65 & 41.7 & 41.2 \\
\hline $10 \mathrm{c}$ & 5.3 & 672.6 & 675.3 & 362.3 & 39.25 & 38.3 & 38.55 & 37.65 \\
\hline $15 a$ & 5.3 & 627.2 & 629.9 & 339.7 & 38.3 & 39 & 40.5 & 39.8 \\
\hline $15 b$ & 5.3 & 617.8 & 620.3 & 333.1 & 34.55 & 34.3 & 35.7 & 32.55 \\
\hline $15 c$ & 5.3 & 702.8 & 705.6 & 382.4 & 42.25 & 43.35 & 43.1 & 43.2 \\
\hline $20 \mathrm{a}$ & 5.3 & 674.2 & 680.9 & 364.4 & 39.8 & 38.95 & 38.9 & 38.35 \\
\hline $20 \mathrm{~b}$ & 5.3 & 647.2 & 653.5 & 348.8 & 38.75 & 38.1 & 39.5 & 38.95 \\
\hline $20 c$ & 5.3 & 719.5 & 724.3 & 388.6 & 41.5 & 41.6 & 40.4 & 40.1 \\
\hline
\end{tabular}

Dari data berat masing-masing benda uji pada tabel 7 kemudian diolah untuk mencari nilai volumetrik campuran yang diaplikasikan di lapangan yaitu nilai densitas, nilai void in mix dan nilai specific gravity mix. 
Tabel 8. Hasil uji volumetrik sampel coring

\begin{tabular}{|c|c|c|c|}
\hline $\begin{array}{l}\text { KODE } \\
\text { SAMPEL }\end{array}$ & $\begin{array}{l}\text { DENSITY } \\
\text { (GR/CM) }\end{array}$ & $\begin{array}{c}\text { SPECIFIC GRAFITY } \\
\text { MIX (GR/CM })\end{array}$ & 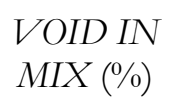 \\
\hline $10 \mathrm{~A}$ & 2.172 & \multirow{3}{*}{2.370} & 8.34 \\
\hline $10 \mathrm{~B}$ & 2.127 & & 10.23 \\
\hline $10 \mathrm{C}$ & 2.149 & & 9.32 \\
\hline rata - rata & 2.149 & rata - rata & 9.30 \\
\hline $15 \mathrm{~A}$ & 2.161 & \multirow{3}{*}{2.370} & 8.80 \\
\hline $15 \mathrm{~B}$ & 2.151 & & 9.22 \\
\hline $15 \mathrm{C}$ & 2.175 & & 8.24 \\
\hline rata - rata & 2.162 & rata - rata & 8.75 \\
\hline $20 \mathrm{~A}$ & 2.130 & \multirow{3}{*}{2.370} & 10.11 \\
\hline $20 \mathrm{~B}$ & 2.149 & & 9.30 \\
\hline $20 \mathrm{C}$ & 2.268 & & 4.29 \\
\hline rata - rata & 2.183 & rata - rata & 7.90 \\
\hline
\end{tabular}

Pada Tabel 8 menunjukkan hasil perhitungan nilai volumetrik campuran yaitu nilai densitas, nilai void in mix dan nilai specific gravity mix. Berdasarkan data diatas menunjukkan semakin banyak lintasan maka nilai volumetrik semakin baik, namun memiliki nilai yang asimptotis.

\section{KESIMPULAN}

Setelah dilakukan penelitian tentang Thin Surfacing Hot Mix Asphalt didapat kesimpulan sebagai berikut:

1. Dari penelitiandiketahui bahwa campuran Thin Surfacing Hot Mix Asphalt dengan starbit E-55 mempunyai nilai stabilitas dan marshall quotient tertinggi yaitu stabilitas sebesar 1.024,60 kg dan marshall quotient sebesar 466,09 kg/mm.

2. Job Mix FormulaThin Surfacing Hot Mix Asphalt dengan campuran Starbit E-55 untuk pengaplikasian di lapangan yaitu:
i. Kadar aspal optimum
$=5,3 \%$
ii. Agregat
$=94,7 \%$

Komposisi agregat yang digunakan terdiri dari :
a. Agregat ukuran 1' $=46 \%$
b. Agregat ukuran $1 / 2^{\prime}=26 \%$
c. Abu Batu = $28 \%$

Dari data diatas untuk pembuatan benda uji ukuran $3 \mathrm{~m} \times 1 \mathrm{~m} \times 3 \mathrm{~cm}$ dibutuhkan material 10,653 kg aspal starbit E-55, agregat ukuran 1' sebanyak 87,56 kg, agregat ukuran 1/2' sebanyak 49,49 $\mathrm{kg}$ serta abu batu sebanyak 52,30 kg.

3. Dengan perbedaan variasi gilasan pada benda uji yaitu sebanyak 10,15 , dan 20 gilasan dihasilkan nilai volumetrik yang semakin baik namun memiliki nilai yang asimptotik. 


\section{UCAPAN TERIMAKASIH}

Ucapan terima kasih kepada Ir. Ary Setyawan, M.Sc., Ph.D. dan Ir. Agus Sumarsono, MT yang telah membimbing, memberi arahan dan masukan dalam penelitian ini.

\section{REFERENSI}

Sujatmiko, G. F., Setyawan, A., \& Sanusi, S. (2014). Kekuatan Danketahanan Lapis Pada Tipis Campuran Aspal Panas Dengan Retona Blend 55. Matriks Teknik Sipil, 2(4).

Febrianto, N., Setyawan, A., \& Sarwono, D. (2014). Sifat-Sifat Marshallpada Lapis Tipis Campuran Aspal Panas Dengan Penambahan Crumb Rubber. Matriks Teknik Sipil, 2(4).

Sukmana, S., Setyawan, A., \& Djumari, D. (2014). Sifat-Sifat Marshall Pada Lapis Tipis Campuran Aspal Panas Dengan Penggunaan Retona Blend55. Matriks Teknik Sipil, 2(4).

Novriandi, P. (2016). Sifat-Sifat Marshall Pada Lapis Tipis Campuran Aspal Panas Menggunakan Aspal Modifikasi Ethylene Vinyl Acetate (Eva) , (UniversitasSebelas Maret).

Kurniawan, R., Setyawan, A., \& Djumari, D. (2016). Pengarub Bitumenmodifikasi Ethylene Vinyl Acetate (Eva) Pada Asphalt Concrete Dan Thin Surfacing Hot Mix Asphalt Terbadap Pengujian Unconfined Compressive Strength (Ucs) Dan Indirect Tensile Strength (Its). Matriks Teknik Sipil, 4(2).

Iskandar, I., Setyawan, A., \& Legowo, S. J. (2016). Sifat-Sifat Marshall Dan Resilient Modulus Pada Thin Surfacing Hot Mix Asphalt Dengan Polymer Modified Bitumen. Matriks Teknik Sipil, 4(2).

Edwin, I., Setiawan, A., \& Djarwanti, N. (2017). Sifat-Sifat Marshall Pada Lapis Tipis Campuran Aspal Panas Dengan Penggunaan Retona Blend 55. Matriks Teknik Sipil, 5(4). 